\title{
Different disclosure activities and sophisticated investors ${ }^{\star}$
}

\author{
Davi Jônatas Cunha Araújo' ${ }^{1}$ \\ (D) https://orcid.org/0000-0002-7819-5691 \\ Email: davijonatasss@gmail.com \\ Jefferson Pereira de Andrade 1
(D) https://orcid.org/0000-0001-8967-8827
Email: pereira_jp2008@hotmail.com \\ Luiz Felipe de Araújo Pontes Girão ${ }^{1}$ \\ (D) https://orcid.org/0000-0002-3639-7340 \\ Email: luizfelipe@ccsa.ufpb.br
}

1 Universidade Federal da Paraíba, Centro de Ciências Sociais e Aplicadas, Departamento de Finanças e Contabilidade, João Pessoa, PB, Brazil

Received on 10.16.2018 - Desk acceptance on 11.21.2018 - $2^{\text {nd }}$ version approved on 06.26.2019 - Ahead of print on 11.07.2019

Associate Editor: Fernanda Finotti Cordeiro Perobelli

\begin{abstract}
This article aims to verify what the influence is of different disclosure activities on the concentration of more sophisticated investors in Brazilian companies. The study fills a gap regarding the influence that disclosure activities can have on the concentration of sophisticated investors in Brazilian firms, considering that this may occur due to their ability to maximize the usefulness of the information disclosed and the return on investments, with a reduction in the cost of allocated funds. This subject is relevant because it verifies not the clientless effect of disclosure, presented by the only study previously developed on the subject in the United States (Kalay, 2015), but rather the influence that disclosure activities (earnings forecasts, market communications, and investor relations [IR]) have on the most sophisticated investors' decisions to allocate funds in companies in the Brazilian market. As an impact on the area, it was noted that those companies that release market communications attract the investment of funds and the concentration of sophisticated investors much more than those that present better IR and release profit forecasts. We studied 89 publicly-traded companies whose reference forms were published in the period from 2011 to 2016. The number of institutional investors disclosed in the reference forms was used as a proxy to categorize them as more sophisticated. The different disclosure activities were represented by the disclosure of profit forecasts, the number of market communications, and the best IR. The best IR proxy was categorized using the companies awarded by IR Magazine Brazil that presented the best IR in the study period. The results of this study show that the most sophisticated investors concentrated in companies with better IR, in those that do not disclose profit forecasts, and in companies with a greater number of disclosed market communications. The disclosure of market communications is the disclosure activity that most influences the concentration of sophisticated investors in Brazilian companies that use more voluntary disclosure than discretionary disclosure to allocate their funds.
\end{abstract}

Keywords: sophisticated investor, disclosure activities, theory of disclosure.

Correspondence address

Davi Jônatas Cunha Araújo

Universidade Federal da Paraíba, Centro de Ciências Sociais e Aplicadas, Departamento de Finanças e Contabilidade

Campus I Universidade Federal da Paraíba, Via Expressa Padre Zé, 289 - CEP 58051-900

Castelo Branco III - João Pessoa - PB - Brazil

* Paper presented at the Paper Development Workshop of the Review of Business Management, São Paulo, SP, Brazil, June 2018. 


\section{INTRODUCTION}

Investor sophistication can be understood using different focuses. Under the usefulness of information focus, Easley and O'Hara (2010) relate the sophistication of investors with their capacity to maximize the usefulness of the information relating to their investments. When market trading is emphasized, Koehler (2014) indicates that sophisticated investors are able to judge the risk of information, independently of the activity through which it was disclosed.

Disclosure activities can benefit more sophisticated investors when they have the ability to maximize the usefulness of information relating to their investments (Feng \& Seasholes, 2005). These activities can facilitate the understanding of these investors, depending on their capacity to analyze information.

In the only study previously developed on the topic in the United States, Kalay (2015) investigated whether different disclosure activities caused the clientless effect, which consisted of an event in which companies used different disclosure activities to attract more sophisticated investors.

Unlike Kalay (2015), the main contribution of this proposed study to the literature is to verify not the clientless effect of disclosure, but rather the influence of earnings forecasts, market communications, and investor relations (IRs) disclosure activities on the most sophisticated investors' decisions to allocate funds in companies in the Brazilian market.

Two types of disclosure underpinned by the theory of disclosure were selected for this study: the discretionary disclosure of market operations and voluntary disclosure, considering the predictive capacity of investors in both cases and the interest in maximizing the return obtained from investing funds in assets that they believe to have earnings potential (Mao \& Helliwell, 1969).

The classification of the theory between discretionary and voluntary disclosure was used as a support for investigating the influence of the disclosure activities over the allocation of funds by investors in companies. An increase in the precision of the information would reduce market uncertainty (Kim \& Lim, 2011) and influence the most sophisticated investors into concentrating their investments in firms that practice discretionary disclosure. The capacity of sophisticated investors to better evaluate the performance of companies that practice voluntary disclosure provides these investors with an advantage over other investors (Kim \& Verrecchia, 1994) and this influences them into allocating their investments in firms that practice that type of disclosure.

Sophisticated investors want to maximize the return on their investments, and it is via the disclosure activities that these investors make their decisions to allocate funds. If the activity is discretionary, investors will be more likely to use the disclosure of earnings forecasts as a support for allocating their investments; if the activity is voluntary, investors will tend to allocate their investments in companies that communicate better with the market or that are a reference in IR. Sophisticated investors will use the information disclosed voluntarily to make decisions.

Under this approach, the proposed study seeks to answer the following question: what is the influence of disclosure activities on the concentration of more sophisticated investors in Brazilian companies?

Regarding the conceptual relationship between disclosure activities and sophisticated investors, the proposal of this study was built based on the influence (Feng \& Seasholes, 2005)sophistication (static differences across investors that these activities can have on the concentration of sophisticated investors in companies, considering that this may occur due to the capacity of investors to maximize the usefulness of the information disclosed (Easley and O'Hara, 2010). The proposed study is based on both voluntary and obligatory disclosure, separated into three different disclosure activities: better IR (more disclosure), disclosure of earnings forecasts (voluntary), and market communications (obligatory).

The importance of this study lies in verifying whether those companies that present better IR and that release earnings forecasts and market communications also attract a greater quantity of sophisticated investors in Brazil. The proxy used to define sophisticated investors was the number of institutional investors, as used by Sias and Starks (1997) and Girão (2016) in their studies.

The studies by Sias and Starks (1997) and Girão (2016) were chosen because they identified the returns on portfolios dominated by institutional investors that, as they are better informed, outperformed the returns on the portfolios of individual investors (Sias \& Starks, 1997). The quantity of institutional investors and analysts' forecasts were able to optimize company trading on the market by reducing the companies' cost of capital (Girão, 2016). 


\section{THEORETICAL FRAMEWORK}

The theory of disclosure explains that there can be three types of disclosure in the market: external, to investors in general; discretionary, to investors that have prior knowledge of the information; and voluntary, to investors that have no prior knowledge of the information in the market (Verrecchia, 2001).

Independently of the type of disclosure, Hand (1990) demonstrated that institutional investors are the market agents with the most ability to maximize the usefulness of the information disclosed. For Kalay (2015), they are able to maximize the usefulness of information regardless of whether it is public or private.

These investors' capacity to maximize information is related to the fact that they are more sophisticated (Cia, Guarita \& Cia, 2002; Ferri \& Soares, 2009). With regards to this, Kalay (2015) indicates that sophisticated investors are those that have the ability to use the information available to obtain an advantage. These investors make more effective decisions and have more capacity to access different sources of information, especially when that information has not been disclosed voluntarily (Balsam, Bartov \& Marquardt, 2002).

Sophisticated investors in an environment of nonvoluntary disclosure are less susceptible to a lack of impartiality of information. Voluntary disclosure has been used with the aim of promoting the use of management ideas that are able to provide an increase in the potential of companies for the interested parties (Abeysekera \& Guthrie, 2005). All the information disclosed by companies that goes beyond the information required by laws, standards, or regulatory bodies is considered to be voluntary (Zaini, Samkin, Sharma \& Davey, 2018).

Voluntary information can be presented in various forms: monetary, quantitative, non-monetary, and qualitative or narrative. In addition, it occurs at different levels, depending on the circumstances in which it originated (Zaini et al., 2018). Investors with a high level of sophistication dedicate more time to their investments and, for that reason, outperform compared to the rest (Kalay, 2015), especially when avoiding losses and making more assertive decisions in the market is concerned (Ferg \& Seasholes, 2005).

Investment analysts' forecasts enhance the sophistication of investors in the market. A good analysts' forecast influences both the sophistication of investors and the behavior of the market itself to accommodate this type of investor.
The study by Irvine (2004) confirmed that analysts' forecasts have a positive impact on share prices. When these shares become more profitable, there is an increase in the demand on the part of investors for these analysts' forecasts. These analysts' projections influence the effect of the concentration of investments in companies that present better share price performance.

Independently of companies' disclosure in the market being discretionary or voluntary, analysts' forecasts can influence the concentration of more sophisticated investors when they project their recommendations as being the best investment opportunities.

The studies by Bjerring, Lakonishok, and Vermaelen (1983), Moshirian, Ng, and Wu (2009), and Sidhu and Tan (2011) confirmed the influence of analysts' forecasts in three ways: investors tolerate the cost of allocated capital when analysts recommend certain investments with a history of positive and successive returns in the market; analysts tend to recommend these investments as more lucrative opportunities for investors to allocate their funds; and analysts with accurate recommendations concentrate more on investor demands than on external market events when establishing forecasts.

Haziza and Kalay (2014) say that sophisticated investors focus their attentions on investments with a high degree of informational asymmetry and little liquidity so that institutional investors benefit more in environments where there is high asymmetry. In the United States, practicing selective disclosure of information to the market, as well as the "natural" asymmetry between managers and investors, led to asymmetric disclosure among investors themselves. This situation gave rise to the fair disclosure regulation, better known as RegFD, which regulated the disclosure activities of companies participating in the U.S. capital market.

As a result of the enactment of this regulation in the United States, CVM Instruction n. 358 (Brazilian Securities and Exchance Commission - Comissão de Valores Mobiliários [CVM], 2002), which institutionalized disclosure practices in Brazil, was approved in accordance with the RegFD regulations. This instruction foresaw the disclosure of all relevant facts to investors so that information should be disclosed in a comprehensive way and released to all, as supported by the first approach of the theory of disclosure, which supports the general disclosure of information to all investors.

RegFD listed what information should be disclosed and what communication channels should be used so that 
the simultaneous and equal disclosure of that information among investors can occur.

The three classifications of the theory of disclosure (Verrecchia, 2001) support the possibility of different disclosure activities benefiting (or potentially attracting) sophisticated investors.

The interest of investors in enhancing the return obtained from allocating funds in assets they believe to have earnings potential (Mao \& Helliwell, 1969) and the discretionary and voluntary disclosure in the market influence investors in their decisions regarding where to hold the funds invested. This can be explained by the level of sophistication of these investors in maximizing the usefulness of the information disclosed and the return on their investments by reducing the cost of allocated capital. This approach supports the following research hypothesis:

$\mathrm{H}_{1}$ : different disclosure activities positively influence the concentration of more sophisticated investors in Brazilian companies.

With the assumption that the information disclosed through different disclosure activities can positively influence the concentration of more sophisticated investors (Balsam, Bartov \& Marquardt, 2002), the proxy used to define the level of sophistication was the quantity of institutional investors of companies listed on the Brasil, Bolsa, Balcão (B3) exchange, as according to the studies by Balsan et al. (2002), Kimball and Shumway (2010), Koehler (2014), and Girão (2016).

Girão (2016) used the quantity of institutional investors to categorize the dependent variable of the proposed theoretical model. The number of investors was used as a proxy for competition for better information as being able to reduce the cost of own capital in companies located in a previously poor institutional environment.

Kimball and Shumway (2010) related the sophistication of investors to the size of their participation in international investments, to the diversification measures used by them, and to their participation in equities. The authors discovered that sophisticated investors are more likely to master a greater quantity of information, which leads them to invest more in the capital market or to hold their investments in a particular company.

Koehler (2014) highlighted that sophisticated investors are able to judge the risk of information even before that information is disclosed.

Balsam et al. (2002) studied the relationship between investor sophistication, accounting adjustments, and the increase in the net equity value of organizations. The authors proposed that more sophisticated investors are more able to identify discretionary accounting adjustments in financial statements and, consequently, add more value to equity. They also discovered that sophisticated investors, backed by a good analysts' forecast, influence the market's reaction regarding the price of the securities traded. In turn, the occurrence of these events is favored by the existence of different disclosure activities that influence the actions of sophisticated investors in the market.

Ranking companies that present better IR can lead to a psychological effect on institutional investors so that they will focus their investments in companies that always present a good IR concept. In addition, companies that present better IR also present better financial results, which can contribute to concentrating institutional investors in these companies (Balsam et al., 2002).

In the case of disclosing earnings forecasts and market communications, more sophisticated investors tend to use that information to allocate a greater sum of funds to companies that present better payment forecasts in terms of returns on shareholder investments and, consequently, institutional investors tend to concentrate in companies that communicate better with the market (Girão, 2016).

The proxies for defining the disclosure activities were characterized by the IR Magazine Brazil (http: //events. irmagazine.com /brazil/) awards to the companies that had the best IR and disclosure of market communications and of earnings forecasts extracted from the reference forms of the firms in the sample, as according to the study by Kalay (2015). That study, in turn, identified that the demand for disclosure from sophisticated investors is partially driven by their capacity to use the information, which may be favored by the type of disclosure activity.

\section{METHODOLOGICAL PROCEDURES}

\subsection{Universe and Sample}

To achieve the research objective, the time horizon was defined according to the availability of the data collected from the reference forms and from the Thomson Reuters ${ }^{\circledR}$ database.

Reference forms, the main source of data, only became obligatory in 2010; however, if the time period of the study 
was defined as starting in the first year the report was mandatory, the sample studied would be reduced, since balanced panel data were chosen and some companies did not present all the necessary data, thus implying a study period between 2011 and 2016.

Although the focus of the study is the period from 2011 to 2016, the data relating to 2010 were used as a sensitivity test for the results, as described in section 3.3 (Control Variables and Econometric Model).

The universe studied covered all the companies that trade shares on the B3, totaling 475 . The research sample was defined based on active companies, excluding those from the financial sector, those with a greater number of institutional investors than the total number of Brazilian investors, and those that did not present the necessary data for all the years.

The final sample was composed of 89 companies listed on the B3 and with available data between 2011 and 2016, as described in Table 1.

\section{Table 1}

Research sample

\begin{tabular}{lcc}
\hline Criteria & Companies (n) & $\%$ \\
\hline $\begin{array}{l}\text { Companies listed on the Brasil, Bolsa, } \\
\text { Balcão exchange }\end{array}$ & 475 & 100 \\
\hline $\begin{array}{l}\text { (-) Companies listed in the financial } \\
\text { sector }\end{array}$ & 200 & 42.11 \\
\hline $\begin{array}{l}\text { (-) Companies with missing data or } \\
\begin{array}{l}\text { a greater number of institutional } \\
\text { investors than the Brazilian total }\end{array}\end{array}$ & 186 & 39.16 \\
\hline (=) Final sample & 89 & 18.73 \\
\hline
\end{tabular}

Source: Elaborated by the authors.

The companies from the financial sector were excluded from the sample for carrying out activities with their own institutional characteristics, making the result obtained discrepant in relation to the others.

The impact of eliminating the companies listed as financial sector was to reduce the number that could participate in the study by approximately $42 \%$. This made it impossible to investigate what disclosure activities can influence the concentration of funds allocated by investors in companies from the financial sector, which correspond to almost half of the companies listed on the Brazilian stock market.

A balanced panel was chosen due to the "inconstancy" of the information disclosed by the companies, that is, information or disclosure in a particular year, especially when voluntary, is not necessarily disclosed in the following year, which makes identifying changes in the disclosure strategy of the companies studied difficult (a higher or lower level of disclosure).
Some of the reasons that may explain the "inconstancy" in the disclosure of information on the part of some companies derived from their disclosure strategy. From the perspective of Snow and Hambrick (1980), in order to be able to incorporate strategic changes of the companies being investigated, it is necessary to consider a minimum interval of five years of data for every organization studied, which led the authors of the proposed study to consider the effects of these possible events on the econometric model.

\subsection{Measurement of Investor Sophistication and Disclosure Activities}

To analyze the influence of disclosure activities on the concentration of institutional investors, the methodology of the research in question was based on the study by Kalay (2015). In that study, Kalay (2015) developed a new measure for quantifying sophisticated investors, called open interest, calculated based on data relating to the trading of share options on the U.S. financial market. However, due to the low liquidity in the Brazilian options market compared to the U.S. market, we chose to use a proxy variable in substitution of the measure used.

The proxy variable used to measure the number of sophisticated investors considered the existing literature that defined institutional investors as sophisticated and more able to monitor and discipline company managers (Ferri \& Soares, 2009). In addition, the measure took previous studies into account, such as those by Balsam et al. (2000), Kimball and Shumway (2010), Koehler (2014), and Girão (2016), which used the number of institutional investors as a proxy for sophisticated investors. Institutional investors were defined by Cia et al. (2000) as those that trade a large quantity of shares on global financial markets, which correspond to pension funds, mutual funds, employee funds, insurance companies, and financial institutions.

The proxy called "number of institutional investors" (NII) corresponded to the natural logarithm of the number of institutional investors disclosed in the reference forms plus 1 . Adding the value 1 was an attempt to ensure that even those companies that did not present institutional investors were in the sample studied.

Regarding the different disclosure activities, three different types of communication involving companies and their shareholders were analyzed: IR, earnings forecasts, and market communications.

Concerning IR, better investor relations practices were measured using a dummy variable based on the IR Magazine Brazil awards to companies with the best investor relations programs. For the winning companies, 
the IR dummy variable took the value 1; otherwise the variable took the value 0 .

Earnings forecasts correspond to non-mandatory information; for this reason this was measured based on a dummy variable called earnings estimate (EAR_EST), which took the value 1 when the company disclosed this information in its reference form and 0 when it did not.

Market communications correspond to the obligation described in art. 157, paragraph 4, of Law n. 6,404/1976 and in art. 2 of CVM Instruction n. 358/2002 (CVM, 2002). Companies should issue a market communication whenever any deliberation (of the general meeting or management body) or relevant fact can influence investor decisions, which implies the possibility of not disclosing or disclosing more than one market communication.
In light of this, unlike the previous variables, market communications did not correspond to a dummy variable and their measurement was the result of the natural logarithm of the number of communications disclosed to the markets in the years chosen for the study.

\subsection{Control Variables and Econometric Model}

According to Hoffmann (2015), when analyzing the relationship between two variables it is necessary for other variables that relate with the dependent variables to be inserted into the model, since without the presence of these the effect between the variables of interest may be masked. In this context, and based on the existing literature, the control variables used are presented in Table 2.

Table 2

Control variables

\begin{tabular}{|c|c|c|c|}
\hline Variable & Abbreviation & Expected relationship & Description \\
\hline Market value & LnMAR_VAL & + & $\begin{array}{l}\text { Calculated by the natural logarithm of the product } \\
\text { resulting from the number of shares and the quotation on } \\
\text { December } 31^{\text {st }} \text { of each year. }\end{array}$ \\
\hline Analyst coverage & ANA_COV & + & Corresponds to the number of analysts. \\
\hline Financial leverage & LEV & + & $\begin{array}{c}\text { Ratio between total debts and total assets in the third } \\
\text { quarter of each year. }\end{array}$ \\
\hline Liquidity & IBOV & + & $\begin{array}{l}\text { Dummy variable that takes the value } 1 \text { when the company } \\
\text { features in the theoretical portfolio of the Bovespa Index } \\
\text { and } 0 \text { otherwise. }\end{array}$ \\
\hline Earnings volatility & EAR_VOL & + & $\begin{array}{c}\text { Calculated by the standard deviation of net earnings from } \\
\text { the last five financial years. }\end{array}$ \\
\hline Market-to-book & MAR_BOOK & - & $\begin{array}{c}\text { Calculated by the ratio between the book value and the } \\
\text { market value. }\end{array}$ \\
\hline Total return & TOT_RET & + & $\begin{array}{l}\text { Calculated by the In (closing value - opening value)/ } \\
\text { closing value in the last three months. }\end{array}$ \\
\hline Returns volatility & RET_VOL & - & $\begin{array}{l}\text { Indicated by the standard deviation of the daily returns in } \\
\text { the last } 60 \text { days. }\end{array}$ \\
\hline Value due to the shareholder & LnVAL_DUE & - & Indicated by the total dividends payable. \\
\hline
\end{tabular}

Source: Kalay (2015).

After defining the variables, the analysis of the relationships between them was carried out via the regression analysis statistical technique, using the ordinary least squares (OLS) estimator with balanced panel data and year and sector fixed effects, as according to equation 1 .

$$
\begin{aligned}
& \ln (\mathrm{NII}+1)_{\text {it }}=\beta 0_{\text {it }}+\beta 1^{\star} \text { Disclosure activity }_{\text {it }}+\beta 2^{\star} \ln \left(\mathrm{MAR}_{-} \mathrm{VAL}\right)_{\text {it }}+\beta 3^{\star} \mathrm{ANA}_{-} \mathrm{COV}_{\text {it }}+\beta 4_{\text {it }}{ }^{\star} \mathrm{LEV} \\
& +\beta 5_{\mathrm{it}}{ }^{*} \mathrm{IBOV}+\beta 6^{\star} \ln \left(\mathrm{EAR} \_\mathrm{VOL}\right)_{\mathrm{it}}+\beta 7^{*} \mathrm{MAR} \_\mathrm{BOOK}{ }_{\mathrm{it}}+\beta 8^{\star} \mathrm{TOT}_{-} \mathrm{RET}_{\mathrm{it}}-\beta 9^{\star} \mathrm{RET}_{-} \mathrm{VOL}_{\mathrm{it}}+ \\
& \beta 10^{\star} \ln (\text { VAL_DUE })_{\mathrm{it}}+\text { Year/Sector }+\varepsilon_{\mathrm{it}}
\end{aligned}
$$


To analyze the persistence of the results simultaneously, besides the model presented in equation 1 , for each variable related to the disclosure activities used in the research two more regressions were run.

The first, originating from the variable dispersion analysis, aimed to verify the persistence of the results after removing the variables with the greatest dispersion (market value, earnings volatility, and value due to the shareholder), implying a sensitivity test of the outliers.
The second regression represented the persistence analysis in relation to the number of observations; for this, as already mentioned in section 3.1 (Universe and Sample), data relating to 2010 were used in an unbalanced panel.

Finally, to test the sensitivity of the model to the outliers, a median quantile regression was run, conserving all the variables of the original model and as described in the model presented as equation 2 .

$$
\begin{aligned}
& (\mathrm{NII}+1)_{\mathrm{it}}=\beta 0_{\mathrm{it}}+\beta 1^{\star} \text { Disclosure } \text { activity }_{\mathrm{it}}+\beta 2^{\star} \mathrm{MAR}_{-} \mathrm{VAL}_{\mathrm{it}}+\beta 3^{\star} \mathrm{ANA}_{-} \mathrm{COV}_{\mathrm{it}}+\beta 4_{\mathrm{it}}{ }^{*} \mathrm{LEV}+ \\
& \beta 5_{\text {it }}^{*} \mathrm{IBOV}^{\mathrm{it}}+\beta 6^{\star} \mathrm{EAR}_{2} \mathrm{VOL}_{\mathrm{it}}+\beta 7^{\star} \mathrm{MAR} \_\mathrm{BOOK}_{\mathrm{it}}+\beta 8^{*} \mathrm{TOT}_{-} \mathrm{RET}_{\mathrm{it}}-\beta 9^{*} \mathrm{RET}_{-} \mathrm{VOL}_{\mathrm{it}}+ \\
& \beta 10^{*} \mathrm{VAL} \_\mathrm{DUE} \mathrm{it}_{\mathrm{it}}+\text { Year } / \text { Sector }+\varepsilon_{\mathrm{it}}
\end{aligned}
$$

\section{RESULTS ANALYSIS}

The results analysis took place in three stages, as according to the subsections below: descriptive statistics; multiple regressions analysis, including the correlation matrix; and sensitivity analysis using median quantile regression.

\subsection{Descriptive Statistics}

The descriptive statistics analysis involved central and dispersion tendency measures of the variables corresponding to investor sophistication and to the disclosure activities (Table 3 ).

Table 3

Descriptive statistics of the disclosure variables and of the most sophisticated investors

\begin{tabular}{lccccc}
\hline Variable & Mean & Standard deviation & Min. & Max. & Observations (n) \\
\hline INST_INV & 409.69 & 758.68 & 0 & 7,687 & 528 \\
\hline COMM & 15.26 & 13.76 & 0 & 115 & 528 \\
\hline IR & 0.7576 & 0.2648 & 0 & 1 & 528 \\
\hline EAR_EST & 0.3674 & 0.4825 & 0 & 1 & 528 \\
\hline
\end{tabular}

COMM = number of market communications; EAR_EST = disclosure of earnings forecasts; INST_INV = number of institutional investors; IR = investor relations.

Source: Elaborated by the authors.

According to Table 3 , the mean quantity of institutional investors (INST_INV) presented by the companies was approximately 410 investors, with a standard deviation of 759 , considering a maximum value of 7,587 investors and minimum of 0 . The breadth of data and the high standard deviation indicate the high level of divergence in the quantity of institutional investors among the sample companies. In addition, the minimum value 0 , from the perspective adopted for measuring sophistication, indicates that some companies have no investors with this profile.

The descriptive analysis of market communications (COMM) indicated a mean disclosure of approximately 15 communications, considering a standard deviation of the mean of approximately 14 communications for this disclosure activity. The greatest number of market communications was published in 2016, corresponding to a total of 115 communications. Fourteen companies in the sample did not publish market communications, and six did not publish communications for more than one year, totaling 19 observations among the total analyzed.

Regarding the descriptive analysis of the IR Magazine awards (IR) and of the operational and earnings forecasts (EAR_EST), both variables are represented by binary variables, thus implying a low dispersion of the data in relation to the other variables. The best IRs indicated by IR Magazine and described by the IR variable contemplate 14 award categories, which resulted in 21 sample companies receiving the award, with some receiving it in more than one year, resulting in 40 awarded companies over the six years; the mean of the observations corresponds to 0.75 and the standard deviation to 0.26 . 
Disclosure of earnings forecasts is not mandatory; thus, not all disclosed this information, which implied a total of 194 disclosed forecasts among 528 forms analyzed. The mean of 0.36 and standard deviation of 0.48 are a reflection of the discrepancy between the number of companies that published and those that did not publish this information.

Considering the dispersion in the number of institutional investors (INST_INV), the number of market communications (COMM), and seeking to avoid possible econometric problems with relation to homogeneity, the other analyses were developed using the natural logarithm of these variables.

\subsection{Relationship between Disclosure Activities and Sophisticated Investors}

After analyzing the descriptive statistics, the analysis of the relationship between the variables corresponding to the disclosure activities and sophisticated investors (indicated by the number of institutional investors) was carried out using the Pearson correlation test and is shown in Table 4.

Table 4

Correlation matrix between the disclosure and sophisticated investors variables

\begin{tabular}{|c|c|c|c|c|c|c|c|c|c|c|c|c|c|c|}
\hline & & (1) & (2) & (3) & (4) & (5) & (6) & (7) & (8) & (9) & (10) & (11) & (12) & (13) \\
\hline (1) & InINST_INV & 1 & & & & & & & & & & & & \\
\hline \multirow{2}{*}{ (2) } & \multirow{2}{*}{ IR } & 0.21 & 1 & & & & & & & & & & & \\
\hline & & 0.00 & & & & & & & & & & & & \\
\hline \multirow{2}{*}{ (3) } & \multirow{2}{*}{ InCOMM } & 0.51 & 0.11 & 1 & & & & & & & & & & \\
\hline & & 0.00 & 0.00 & & & & & & & & & & & \\
\hline \multirow{2}{*}{ (4) } & \multirow{2}{*}{ EAR_EST } & 0.19 & 0.12 & 0.23 & 1 & & & & & & & & & \\
\hline & & 0.00 & 0.00 & 0.00 & & & & & & & & & & \\
\hline \multirow{2}{*}{ (5) } & \multirow{2}{*}{ InMAR_VAL } & 0.60 & 0.19 & 0.43 & 0.25 & 1 & & & & & & & & \\
\hline & & 0.00 & 0.00 & 0.00 & 0.00 & & & & & & & & & \\
\hline \multirow{2}{*}{ (6) } & \multirow{2}{*}{ ANA_COV } & 0.14 & 0.03 & 0.09 & 0.06 & 0.01 & 1 & & & & & & & \\
\hline & & 0.00 & 0.51 & 0.50 & 0.21 & 0.79 & & & & & & & & \\
\hline \multirow{2}{*}{ (7) } & \multirow{2}{*}{ LEV } & -0.10 & -0.05 & 0.01 & -0.01 & -0.14 & 0.09 & 1 & & & & & & \\
\hline & & 0.04 & 0.22 & 0.71 & 0.81 & 0.00 & 0.04 & & & & & & & \\
\hline \multirow{2}{*}{ (8) } & \multirow{2}{*}{ IBOVESPA } & 0.52 & 0.13 & 0.34 & 0.15 & 0.58 & 0.06 & 0.00 & 1 & & & & & \\
\hline & & 0.00 & 0.00 & 0.00 & 0.00 & 0.00 & 0.16 & 0.98 & & & & & & \\
\hline \multirow{2}{*}{ (9) } & \multirow{2}{*}{ InEAR_VOL } & 0.47 & 0.05 & 0.41 & 0.17 & 0.55 & 0.03 & 0.14 & 0.59 & 1 & & & & \\
\hline & & 0.00 & 0.24 & 0.00 & 0.00 & 0.00 & 0.57 & 0.00 & 0.00 & & & & & \\
\hline \multirow{2}{*}{ (10) } & \multirow{2}{*}{ MAR_BOOK } & -0.12 & -0.03 & -0.10 & -0.07 & 0.06 & -0.06 & -0.01 & -0.05 & 0.02 & 1 & & & \\
\hline & & 0.01 & 0.56 & 0.01 & 0.10 & 0.14 & 0.19 & 0.78 & 0.24 & 0.67 & & & & \\
\hline \multirow{2}{*}{ (11) } & \multirow{2}{*}{ TOT_RET } & 0.09 & 0.11 & 0.06 & 0.03 & 0.25 & -0.04 & -0.13 & 0.10 & 0.06 & 0.06 & 1 & & \\
\hline & & 0.06 & 0.01 & 0.13 & 0.54 & 0.00 & 0.39 & 0.00 & 0.02 & 0.15 & 0.14 & & & \\
\hline \multirow{2}{*}{ (12) } & \multirow{2}{*}{ RET_VOL } & -0.06 & -0.04 & 0.00 & -0.03 & -0.03 & -0.03 & 0.03 & -0.05 & -0.05 & 0.02 & 0.05 & 1 & \\
\hline & & 0.22 & 0.36 & 0.82 & 0.43 & 0.49 & 0.56 & 0.55 & 0.25 & 0.27 & 0.65 & 0.21 & & \\
\hline \multirow{2}{*}{ (13) } & \multirow{2}{*}{ LnVAL_DUE_SHA } & 0.28 & 0.09 & 0.24 & 0.07 & 0.55 & -0.11 & -0.07 & 0.32 & 0.36 & 0.06 & 0.15 & -0.04 & 1 \\
\hline & & 0.00 & 0.05 & 0.00 & 0.15 & 0.00 & 0.01 & 0.11 & 0.00 & 0.00 & 0.16 & 0.00 & 0.41 & \\
\hline
\end{tabular}

Note: the values in bold correspond to the Pearson correlation coefficient and the values below these correspond to the p-value. Source: Elaborated by the authors.

According to Table 4, all the correlations involving the dependent variable and the disclosure variables were significant and positive, but with different intensities. The natural logarithm of the quantity of market communications (lnCOMM) presented a positive correlation of 0.51 which, according to Dancey and Reidy (2019), represents a moderate correlation with the quantity of institutional investors, thus providing indications of the relationship between the number of sophisticated investors and number of market communications issued by the companies. 
The IR variable presented a correlation with the number of institutional investors (lnINST_INV) of 0.21 and the earnings forecasts variable (EAR_EST) presented a correlation of 0.19 . Both correlations, although significant and positive, are considered "weak", indicating a lower level of relationship between the variables analyzed.

Regarding the other variables, only one did not present a relationship with the number of institutional investors: returns volatility (RET_VOL). Only four variables presented moderate correlations: the logarithm of the number of market communications (0.40), the logarithm of market value (0.60), the Bovespa Index (Ibovespa) (0.52), and the logarithm of earnings volatility (0.47). The others presented a low correlation which, according to Dancey and Reidy (2019), is characterized as below 0.39 .

The coefficients of correlation between the logarithm of market value and the Ibovespa (0.58), InEAR_VOL (0.55), and lnVAL_DUE_SHA (0.55) variables, the Ibovespa and volatility dependent variables, InMAR_VAL and lnCOMM, and lnEAR_VOL and lnCOMM of earnings also presented a positive, significant, and moderate correlation.

To deepen the analysis of the correlation between these variables, the multiple regression analysis will be presented below. Table 5 shows the results for the analysis of the relationship between more sophisticated investors and the IR variable.

According to Bushee and Miller (2012), an improvement in IR provides benefits regarding investment attributes, thus promoting an increase in the number of institutional investors. In addition, the strategy of improving IR also aims to reach individual investors, leading to a positive expectation with regards to the IR variable.

Tables 5, 6, and 7 present three regressions. Regressions I and II correspond to the results of the balanced panel with data from the period from 2011 to 2016, as presented in the methodology. However, due to the existence of outliers, the regression was run without the InMAR VAL, lnEAR_VOL, and lnVAL_DUE_SHA variables. Regression III corresponds to the unbalanced panel with data from the period from 2010 to 2016.

Table 5

Analysis of the relationship between investor relations (IR) and sophisticated investors

Panel A

\begin{tabular}{|c|c|c|c|c|}
\hline Variables & Expectation & (I) & (II) & (III) \\
\hline \multirow{2}{*}{ IR } & $(+)$ & 0.6396 & 0.9455 & -0.9828 \\
\hline & & $(0.1976)^{* * *}$ & $(0.1955)^{* * *}$ & $(0.9612)$ \\
\hline \multirow{2}{*}{ Ln MAR_VAL } & $(+)$ & 0.517 & - & 0.6770 \\
\hline & & $(0.5482)^{* * *}$ & - & $(0.0656)^{* * *}$ \\
\hline \multirow{2}{*}{ ANA_COV } & $(+)$ & 0.0215 & 0.0186 & 0.0322 \\
\hline & & $(0.0110)^{*}$ & $(0.0121)$ & $(0.0184)^{*}$ \\
\hline \multirow{2}{*}{ LEV } & $(+)$ & -1.2021 & -0.6593 & 0.7641 \\
\hline & & $(0.4445)^{* * *}$ & $(0.4368)$ & $(0.7070)$ \\
\hline \multirow{2}{*}{ IBOVESPA } & $(+)$ & 0.534 & 1.8129 & 0.6826 \\
\hline & & $(0.1722)^{* * *}$ & $(0.1236)^{* * *}$ & $(0.3503)^{*}$ \\
\hline \multirow{2}{*}{ Ln EAR_VOL } & $(+)$ & 0.211 & - & 0.2704 \\
\hline & & $(0.0791)^{* * *}$ & - & $(0.0905)^{* * *}$ \\
\hline \multirow{2}{*}{ MAR_BOOK } & $(-)$ & -0.0007 & -0.0005 & -0.0006 \\
\hline & & $(0.0002)^{* *}$ & $(0.0001)^{* * *}$ & $(0.0001)^{* * *}$ \\
\hline \multirow{2}{*}{ TOT_RET } & $(+)$ & -0.2089 & 0.4135 & -0.1494 \\
\hline & & $(0.3600)$ & $(0.2613)$ & $(0.4001)$ \\
\hline \multirow{2}{*}{ RET_VOL } & $(-)$ & -0.0034 & -0.0024 & -0.0069 \\
\hline & & $(0.004)$ & $(0.0110)$ & $(0.0034)^{* *}$ \\
\hline \multirow{2}{*}{ Ln VAL_DUE_SHA } & $(-)$ & -0.0272 & - & -0.0415 \\
\hline & & $(0.0299)$ & - & $(0.0454)$ \\
\hline \multirow{2}{*}{ INTERCEPT } & & -1.6413 & 4.3874 & -4.0647 \\
\hline & & $(0.9235)^{*}$ & $(0.2555)^{* * *}$ & $(0.9616)^{* * *}$ \\
\hline Fixed effects & & Year/sector & Year/sector & Year/sector \\
\hline
\end{tabular}


Table 5

Cont.

\begin{tabular}{|c|c|c|c|c|}
\hline \multirow[b]{2}{*}{ Variables } & \multicolumn{4}{|c|}{ Panel B } \\
\hline & Expectation & (I) & (II) & (III) \\
\hline Adjusted $\mathrm{R}^{2}$ & & 0.5179 & 0.3598 & 0.4454 \\
\hline $\mathrm{F}$ test & & $20.34^{* * *}$ & $13.45^{* * *}$ & $31.22^{* * *}$ \\
\hline Jarque-Bera & & $21.66^{* * *}$ & $7.891^{* *}$ & $64.91^{* * *}$ \\
\hline VIF (mean) & & 1.61 & 1.38 & 1.60 \\
\hline White & & $278.06^{* *}$ & $207.17^{* *}$ & $274.34^{*}$ \\
\hline Wooldridge & & 0.905 & 2.6 & $20.87^{* * *}$ \\
\hline
\end{tabular}

Notes: the betas relating to regressions I, II, and III are shown in bold in panel A; the standard error is presented below the betas, in parentheses; panel $B$ represents the result of the analysis of the regression assumptions.

***, ${ }^{* *}, *$ significant at 1,5 , and $10 \%$, respectively.

Source: Elaborated by the authors.

Table 5 is divided into two sections, in which the first (panel A) presents the coefficients of the regressions in which the time and sector fixed effects were considered. Regression I presented the coefficients obtained, as well as the White robust standard error for heteroscedastity, when the number of institutional investors (InINST_INV) was related with the IR variable.

Panel B presented the tests carried out for the analysis of the regression assumptions, as well as the adjusted coefficient of determination. It was verified that the residuals of the regression did not present a normal distribution and, according to the central limit theorem, this assumption can be relaxed, since the mean of a particular sample always converges to the normal distribution as the sample increases (Brooks, 2014).

The proxy used for the IR measurement was shown to be significant at $1 \%$, revealing the positive relationship between the IR Magazine award and the number of institutional investors, implying that the company being awarded increases the logarithm of the number of institutional investors by 0.94 , ceteris paribus.

Due to this relationship, when the companies were awarded by IR Magazine, the variables relating to total returns, returns volatility, and value due to the shareholder did not present a significant relationship with the number of institutional investors. This relationship can be explained by the focus of the theory of disclosure, since more sophisticated investors process earnings forecasts only when private information about company performance is disclosed (Kim \& Verrecchia, 1994).

To analyze the robustness and persistence of regression I, regressions II and III were run. In regression II, the company size (ln_MAR_VAL), earnings volatility (EAR_ VOL), and value due to the shareholder (lnVAL_DUE_ SHA) variables were excluded, since these variables, even after standardization by the natural logarithm calculation, still presented some outliers.

As in the results presented in regression I, regression II also presented problems relating to the normality and heteroscedasticity of the residuals (panel B); corrected by the White robust standard error, the IR variable remained significant and positive, as the model expected. The coefficient presented a 0.3 increase in relation to equation 1 and the adjusted coefficient of determination decreased to 0.36 . The analyst coverage (ANA_COV) and leverage (LEV) variables lost statistical significance in regression II.

Regression III was calculated based on an unbalanced panel with the insertion of data relating to 2010, increasing the number of observations and totaling 96 companies. The standard error presented corresponds to the NeweyWest robust standard error due to the heteroscedasticity and autocorrelation problems. The result of this regression revealed sensitivity of the results when the number of observations was increased, since the relationship between the variables did not persist, implying the absence of a relationship between the variables tested. According to Kalay (2015), better IR means the disclosure of information is greater, as well as making it clearer, which favors less sophisticated investors. The author also explains that less sophisticated investors are the main ones to benefit from this information.

The analysis of the second regression verified the relationship between the number of institutional investors (lnINST_INV) and the disclosure of earnings forecasts 
(EAR_EST), as shown in Table 6. Earnings forecasts provide relevant information for investors that helps them to form expectations about future earnings and they are indicated by the literature as a basis for decisions, especially of sophisticated investors (Kalay, 2015). Thus, the expectation is for the EAR_EST variable to have a positive coefficient.

Table 6

Analysis of the relationship between earnings forecasts and sophisticated investors

\begin{tabular}{|c|c|c|c|c|}
\hline \multirow[b]{2}{*}{ Variable } & \multicolumn{4}{|c|}{ Panel A } \\
\hline & Expectation & (I) & (II) & (III) \\
\hline \multirow{2}{*}{ EAR_EST } & $(+)$ & 0.1000 & 0.288 & -0.2028 \\
\hline & & $(0.1439)$ & $(0.1474)^{*}$ & $(0.2354)$ \\
\hline \multirow{2}{*}{ Ln MAR_VAL } & $(+)$ & 0.5255 & - & 0.6907 \\
\hline & & $(0.0552)^{* * *}$ & - & $(0.0667)^{* * *}$ \\
\hline \multirow{2}{*}{ ANA_COV } & $(+)$ & 0.0189 & 0.0135 & 0.0313 \\
\hline & & $(0.0112)^{*}$ & $(0.0125)$ & $(0.0183)^{*}$ \\
\hline \multirow{2}{*}{ LEV } & $(+)$ & -1.323 & -0.8454 & 0.8048 \\
\hline & & $(0.4478)^{* * *}$ & $(0.4364)^{*}$ & $(0.7094)$ \\
\hline \multirow{2}{*}{ IBOVESPA } & $(+)$ & 0.5519 & 1.8607 & 0.6867 \\
\hline & & $(0.1695)^{* * *}$ & $(0.1255)^{* * *}$ & $(0.3477)^{* *}$ \\
\hline \multirow{2}{*}{ Ln EAR_VOL } & $(+)$ & 0.2105 & - & 0.2736 \\
\hline & & $(0.0799)^{* * *}$ & - & 0.0994 \\
\hline \multirow{2}{*}{ MAR_BOOK } & $(-)$ & -0.0007 & -0.0005 & -0.0006 \\
\hline & & $(0.0002)^{* * *}$ & $(0.0001)^{* * *}$ & $(0.0001)^{* * *}$ \\
\hline \multirow{2}{*}{ TOT_RET } & $(+)$ & -0.1625 & 0.4985 & -0.1248 \\
\hline & & $(0.4160)$ & $(0.2902)^{*}$ & $(0.4057)$ \\
\hline \multirow{2}{*}{ RET_VOL } & $(-)$ & -0.0031 & -0.0016 & -0.0071 \\
\hline & & $(0.0042)$ & $(0.0118)$ & $(0.0033)^{* *}$ \\
\hline \multirow{2}{*}{ Ln VAL_DUE_SHA } & $(-)$ & -0.0189 & - & -0.0469 \\
\hline & & $(0.0308)$ & - & $(0.0465)$ \\
\hline \multirow{2}{*}{ INTERCEPT } & & -1.7435 & 4.3229 & -4.1234 \\
\hline & & $(0.9223)^{*}$ & $(0.2590)^{* * *}$ & $0.9513^{* * *}$ \\
\hline \multirow[t]{2}{*}{ Fixed effects } & & Year/Sector & Year/Sector & Year/Sector \\
\hline & & \multicolumn{2}{|c|}{ Panel B } & \\
\hline Adjusted $\mathrm{R}^{2}$ & & 0.5103 & 0.3462 & 0.4457 \\
\hline F test & & $36.09^{* * *}$ & $29.10^{* * *}$ & $31.12^{* * *}$ \\
\hline Jarque-Bera & & $24.36^{* * *}$ & $9.993^{* * *}$ & $63^{* * *}$ \\
\hline VIF (mean) & & 1.61 & 1.37 & 1.60 \\
\hline White & & $291.20^{* * *}$ & $221.33^{* * *}$ & $305.48^{* * *}$ \\
\hline Wooldridge & & 0.658 & 2.137 & $19.95^{* * *}$ \\
\hline
\end{tabular}

Notes: the betas relating to regressions I, II, and III are shown in bold in panel A; the standard error is presented below the betas, in parentheses; panel $B$ represents the result of the analysis of the regression assumptions.

$* * *, * *, *$ significant at 1,5 , and $10 \%$, respectively.

Source: Elaborated by the authors.

Table 6, like Table 5, is also divided into two sections and presented three regressions. The first section presented the coefficients of the regressions, followed by panel B, which showed the statistics resulting from the tests of the regression assumptions. 
The residuals of the regression did not present a normal distribution, as in the relationship between the quantity of investors and company awards from IR Magazine. With the execution of the White test, problems were also identified relating to the heteroscedasticity in the data, which resulted in the use of the White robust error.

The analysis of the relationship between the coefficients and the dummy variable corresponding to the disclosure of earnings forecasts (EAR_EST) did not present statistical significance, which implies that the disclosure of earnings forecasts is not related with the number of institutional investors and, consequently, with more sophisticated investors.

Under the lens of the third perspective of the theory of disclosure, this result can be explained by the fact that companies only disclose such projections when they present "good forecasts". In light of this, institutional investors, as agents with a greater capacity to process information, may restrict their use of this information (Kalay, 2015). The results found here are not consistent with those of Kalay (2015), as it is not possible to infer that less sophisticated investors use this information. As previously described, equation 2 represented the persistence of the results when variables are removed from the model. On this point, the problems relating to the normality and multicollinearity of the residuals were also corrected by the White robust error.

The earnings forecasts variable (EAR_EST) was shown to be significant and positive, as expected by the model, in opposition with the result obtained in regression I. The coefficient of the variable presented a 0.188 increase. However, the explanatory power of the model was reduced from 51 to $34.5 \%$. The analyst coverage variable was the only one that lost significance in relation to equation 1 .

Regression III of Table 6, like that of Table 5, was calculated by adding data relating to 2010 in an unbalanced panel. The Newey-White standard error was also calculated. The coefficient of the earnings estimate did not present statistical significance due to the lack of a more robust result, and the relationship between these variables was not confirmed.

The analysis of the third regression sought to verify the relationship between the number of instructional investors (lnINST_INV) and the number of market communications disclosed by the companies, as shown in Table 7. As described by Kalay (2015) with regards to the disclosure of information by companies, less sophisticated investors in particular are expected to benefit, as they use market communications more often.

Table 7

Analysis of the relationship between market communications and sophisticated investors

\begin{tabular}{|c|c|c|c|c|}
\hline \multirow[b]{2}{*}{ Variables } & \multicolumn{4}{|c|}{ Panel A } \\
\hline & Expectation & (I) & (II) & (III) \\
\hline \multirow{2}{*}{ Ln COMM } & $(+)$ & 0.507 & 0.6595 & 0.3120 \\
\hline & & $(0.0754)^{* * *}$ & $(0.0690)^{* * *}$ & $(0.1152)^{* * *}$ \\
\hline \multirow{2}{*}{ Ln MAR_VAL } & $(+)$ & 0.4124 & - & 0.6040 \\
\hline & & $(0.0521)^{* * *}$ & - & $(0.0727)^{* * *}$ \\
\hline \multirow{2}{*}{ ANA_COV } & $(+)$ & 0.0109 & 0.0037 & 0.0300 \\
\hline & & $(0.0114)$ & $(0.0123)$ & $(0.0186)$ \\
\hline \multirow{2}{*}{ LEV } & $(+)$ & -1.4864 & -1.0539 & 0.2724 \\
\hline & & $(0.4045)^{* * *}$ & $(0.3810)^{* * *}$ & (0.6988) \\
\hline \multirow{2}{*}{ IBOVESPA } & $(+)$ & 0.4143 & 1.3081 & 0.6890 \\
\hline & & $(0.1599)^{*}$ & $(0.1282)^{* *}$ & $(0.3579)^{* *}$ \\
\hline \multirow{2}{*}{ Ln EAR_VOL } & $(+)$ & 0.1623 & - & 0.2460 \\
\hline & & $(0.0658)^{*}$ & - & $(0.0917)^{* * *}$ \\
\hline \multirow{2}{*}{ MAR_BOOK } & $(-)$ & -0.0004 & -0.0002 & -0.0004 \\
\hline & & $(0.0001)^{* * *}$ & $(0.0001)^{*}$ & $(0.0001)^{* * *}$ \\
\hline \multirow{2}{*}{ TOT_RET } & $(+)$ & -0.0768 & 0.4348 & -0.0754 \\
\hline & & $(0.3157)$ & $(0.2514)^{*}$ & $(0.3783)$ \\
\hline \multirow{2}{*}{ RET_VOL } & $(-)$ & -0.0032 & -0.0024 & -0.0062 \\
\hline & & $(0.0050)$ & $(0.0106)$ & $(0.0035)^{*}$ \\
\hline
\end{tabular}


Table 7

Cont.

\begin{tabular}{|c|c|c|c|c|}
\hline \multirow[b]{2}{*}{ Variables } & \multicolumn{4}{|c|}{ Panel A } \\
\hline & Expectation & (I) & (II) & (III) \\
\hline \multirow{2}{*}{ Ln VAL_DUE_SHA } & $(-)$ & -0.0054 & - & -0.0398 \\
\hline & & $(0.0286)$ & - & $(0.0459)$ \\
\hline \multirow{2}{*}{ INTERCEPT } & & -1.3695 & 3.0651 & -3.7698 \\
\hline & & $(0.7323)^{*}$ & $(0.2719)^{* * *}$ & $(0.9570)^{* * *}$ \\
\hline \multirow[t]{2}{*}{ Fixed effects } & & Year/Sector & Year/Sector & Year/Sector \\
\hline & \multicolumn{4}{|c|}{ Panel B } \\
\hline Adjusted $\mathrm{R}^{2}$ & & 0.5633 & 0.3419 & 0.4414 \\
\hline F test & & $41.65^{* * *}$ & $32.75^{* * *}$ & $31.39 * * *$ \\
\hline Jarque-Bera & & $42.26^{* * *}$ & $9.627^{* * *}$ & $95.28^{* * *}$ \\
\hline VIF (mean) & & 1.62 & 1.39 & 1.61 \\
\hline White & & $263.61^{*}$ & $203.65^{*}$ & $292.86^{* *}$ \\
\hline Wooldridge & & 0.85 & 2.543 & $17.95^{* *}$ \\
\hline
\end{tabular}

Notes: the betas relating to regressions I, II, and III are shown in bold in panel A; the standard error is presented below the betas, in parentheses; panel $B$ represents the result of the analysis of the regression assumptions.

$* * *, * *, *$ significant at 1,5 , and $10 \%$, respectively.

Source: Elaborated by the authors.

The White test revealed heteroscedastic data corrected by the White robust error. The number of market communications (lnCOMM) disclosure variable was shown to be positive and significant, implying that for every market communication released by the company, the number of institutional investors increases by 0.51 .

As in the regressions presented in tables 5 and 6 , the analysis of the persistence of the results also occurred via the execution of regressions II and III. In equation 2, heteroscedasticity problems were detected, according to the White test, corrected by the robust test. The coefficient of the "number of market communications" variable presented a $1 \%$ probability. In addition, the coefficient showed a 0.15 variation in model II with relation to model I and the adjusted coefficient of determination also saw a reduction from 0.56 in equation 1 to 0.34 in equation 2 . The results of this analysis support the result of the first regression, also presented in Table 5, including all the control variables.

Regression III, whose Newey-West standard error was also used, shows persistence of the result, as the coefficient of the lnCOMM variable kept its significance and sign, only undergoing a reduction in its value in relation to regressions I and II. It shows the relationship between institutional investors and the number of market communications, implying that the increase in the number of sophisticated investors is partly explained by the number of market communications. In the study by Kalay (2015), the relationship with sophistication was shown to be significant, as found here, but that study shows more use of market communications by less sophisticated investors.

The combined analysis of the linear regressions enabled it to be inferred that the level of sophistication of the investors is related to the different disclosure activities, as of the three activities analyzed (number of market communications, better IR actions, and disclosure of earnings forecasts), one was related to the number of institutional investors, used here as a proxy for investor sophistication.

\subsection{Analysis of the Sensitivity of the Model}

After the linear regression analysis, the sensitivity test of the model was carried out using a median quantile regression. The reason for using this test was to verify how the disclosure activities related with the quantity of sophisticated investors, considering the behavior of outliers in the relationship between these variables, as presented in Table 8. 
Table 8

Analysis of disclosure activities vs. sophisticated investors

\begin{tabular}{|c|c|c|c|c|}
\hline \multirow[b]{2}{*}{ Variables } & \multicolumn{4}{|c|}{ Panel A } \\
\hline & Expectation & 0.10 & 0.50 & 0.90 \\
\hline \multirow{2}{*}{ IR } & $(+)$ & 0.981 & 0.649 & 0.766 \\
\hline & & (57.303) & (180.201) & $(1,593.934)$ \\
\hline \multirow{2}{*}{ EAR_EST } & $(+)$ & 0.107 & 0.356 & 0.206 \\
\hline & & (10.214) & (20.018) & $(94.281)$ \\
\hline \multirow{2}{*}{ Ln COMM } & $(+)$ & 0.706 & 0.000 & 0.000 \\
\hline & & $(0.533)$ & $(1.032)^{* * *}$ & $(3.401)^{* * *}$ \\
\hline \multirow{3}{*}{ INTERCEPT } & & 0.053 & 0.048 & 0.527 \\
\hline & & $(19.446)^{*}$ & $(25.603)^{* *}$ & (124.394) \\
\hline & \multicolumn{4}{|c|}{ Panel B } \\
\hline Wald test & & $20.34^{* * *}$ & $20.34^{* * *}$ & $20.34^{* * *}$ \\
\hline
\end{tabular}

Notes: the betas relating to the $0.10,0.50$, and 0.90 quantiles are shown in bold in panel A; the (bootstrap) standard error is presented below the betas, in parentheses; panel $B$ represents the result of the significance analysis of the coefficients of the model using the simultaneous regression calculation.

***, ${ }^{* *},{ }^{*}=$ significant at 1,5 , and $10 \%$, respectively.

Source: Elaborated by the authors.

Table 8 presented the results of the analysis of the relationship between the variables corresponding to IR, the disclosure of earnings forecasts, market communications, and to sophisticated investors. To carry out that test, the variable corresponding to sophisticated investors was included in the model without calculating the natural logarithm $\left(\mathrm{NII}_{\mathrm{it}}\right)$, so that it was possible to verify how the variables of the model interact, considering all the control variables used in the multiple linear regression analysis and ignoring the effect of the normalization of the dependent variable data via the logarithmic calculation.

The Wald test in the three quartiles for the general significance of the coefficients rejected the null hypothesis that poor specification of the model had occurred and supported the result obtained by the $\mathrm{F}$ test regarding the significance of the coefficients in the multiple linear regression models.

The analysis of the regression run by quartiles showed that the sophisticated investors located in the first quartile did not use any of the three disclosure activities for making their investment decisions. The first quartile groups the companies with the lowest concentration of these investors. This result indicates that there is a smaller group of sophisticated investors that do not use any of the three types of disclosure activities to hold their investments in the companies. The analysis in the second quartile supports the result obtained by the multiple linear regression analysis, in which the activities relating to IR and to the disclosure of earnings forecasts were used by the most sophisticated investors to make decisions. Only the disclosure of market communications presented a significant relationship with the sophistication of investors in this quartile.

The result indicated that, of the three disclosure activities, the median group of sophisticated investors only use the disclosure of market communications to make investment decisions, instead of using the disclosure of earnings forecasts or consulting whether the companies they invest in have the best IR, according to the IR Magazine awards.

The analysis in the third quartile supports the result of the second quartile and the general result obtained in the multiple linear regression analysis. The variables corresponding to the disclosure of earnings forecasts and to IR did not present a significant relationship with investor sophistication, so that only the disclosure of market communications presented a significant relationship with sophistication.

Based on the median, all the sophisticated investors use the disclosure of market communications to make investment decisions, instead of using disclosed earnings forecasts or whether the companies have been awarded for having better IR, according to the IR Magazine award, and with the same conditions established in the application of the linear regression model. 


\section{CONCLUSION}

The aim of the study was to verify what the influence is of different disclosure activities over the concentration of more sophisticated investors in Brazilian companies, with the assumption being that there was a relationship between these two paradigms (using the lens of the theory of disclosure, especially the second and third classification) and the theoretical approach of investment decisions to maximize earnings and reduce the cost of capital.

To achieve this objective, data on companies listed on the B3 between 2011 and 2016 were used. Investor sophistication was categorized based on the number of institutional investors reported by these companies in their reference forms. Regarding the disclosure activities, three activities were evaluated: number of market communications, IR, and disclosure of earnings forecasts.

As a result, it was verified that, of the three activities studied, only the number of market communications was relevant for the most sophisticated investors to hold a large portion of their investments in the Brazilian companies. Unlike U.S. investors, Brazilian ones do not use earnings forecasts to hold their investments in organizations. This result persisted after the sensitivity test of the data and after the sensitivity test of the model.

This can be explained by the fact that the forecasts being disclosed by the companies themselves are at the mercy of the cognitive effect of optimism or the influence of strong informational asymmetry in companies that trade on the Brazilian capital market.

As a practical contribution, the disclosure of market communications is the disclosure activity that most influences the concentration of sophisticated investors in Brazilian companies, these investors using voluntary more than discretionary disclosure to allocate funds.

Among the main limitations of the study, there is the unavailability of data, when adapting the variables used by Kalay (2015) in the initial version of his study, and the process of adapting the variables itself, given that with the change in scenarios alterations of certain perspectives occur between the studies. Among our suggestions for future research, we recommend including other variables that correspond to other different disclosure activities and another context.

\section{REFERENCES}

Abeysekera, I., \& Guthrie, J. (2005). An empirical investigation of annual reporting trends of intellectual capital in Sri Lanka. Critical Perspectives on Accounting, 16(3), 151-163. http:// dx.doi.org/10.1016/S1045-2354(03)00059-5

Balsam, S., Bartov, E., \& Marquardt, C. (2002). Accruals management, investor sophistication, and equity valuation: Evidence from 10-Q filings. Journal of Accounting Research, 40(4), 987-1012. https://doi.org/10.1111/1475-679X.00079

Bjerring, J. H., Lakonishok, J., Vermaelen, T. (1983). Stock prices and financial analysts' recommendations. Journal of Finance, 38(1), 187-204.

Brooks, C. (2014). Introductory econometrics for finance. 3 ed. Cambridge, Cambs: Cambridge University Press.

Bushee, B. J., \& Miller, G. S. (2012) Investor relations, firm visibility, and investor following. The Accounting Review, 87(3), 867-897. https://doi.org/10.2308/accr-10211

Cia, J. C., Guarita, C. I., \& Cia, J. N. S. (2002). O duplo papel do investidor institucional: influenciador do corporate governance e gestor de carteiras. Anpad. Retrieved from http://www. anpad.org.br/admin/pdf/enanpad2002-fin-1078.pdf

Comissão de Valores Mobiliários (Brazilian Securities and Exchange Commission). (2002). CVM Instruction 358, of January $3^{\text {rd }}$ of 2002. Discusses the disclosure and use of information on relevant acts or facts relating to companies.
Retrieved from http://www.cvm.gov.br/legislacao/instrucoes/ anexos/300/inst358consolid.pdf

Dancey C. P., \& Reidy, J. (2019). Estatística sem matemática para psicologia. 7 ed. Penso Editora Limitada: São Paulo, SP. Retrieved from http://books.google.com.br/books ?id=TSZzDwAAQBAJ\&printsec=frontcover \&hl=pt$\mathrm{BR} \# \mathrm{v}=$ onepage $\& \mathrm{q} \& \mathrm{f}=$ false

Easley, D., \& O'hara, M. (2010). Information and the cost of capital. Finance, 45(4), 993-1018. https://doi. org/10.1111/j.1540-6261.1974.tb00057.x

Feng, L., \& Seasholes, M. S. (2005). Do investor sophistication and trading experience eliminate behavioral biases in financial markets? Review of Finance, 9(3), 305-351. https://doi. org/10.1007/s10679-005-2262-0

Ferri, M. S., \& Soares, R. O. (2009). Investidores institucionais e o foco no curto prazo: um estudo nas empresas negociadas na Bovespa. Contabilidade Vista \& Revista, 20(4), 15-30.

Girão, L. F. D. A. P. (2016). Competição por informações, ciclo de vida e custo do capital no Brasil (Doctorol Thesis). Universidade Federal da Paraíba, João Pessoa.

Hand, J. R. M. (1990). A test of the extended functional fixation hypothesis. The Accounting Review, 65(4), 740-763. Retrieved from https://www.jstor.org/stable /247648 ?seq=1\#page_scan_ tab_contents 
Haziza, M., \& Kalay, A. (2014). Broker rebates and investor sophistication. SSRN. Retrieved from https://ssrn.com/ abstract $=2493693$

Hoffmann, R. (2015). Análise de regressão: uma introdução à econometria. São Paulo, SP: Hucitec.

Irvine, P. J. A. (2004). Analysts' forecasts and brokerage-firm trading. The Accounting Review, 79(1), 125-149.

Kalay, A. (2015). Investor sophistication and disclosure clienteles. Review of Accounting Studies, 20(2), 976-1011. https://doi. org/10.1007/s11142-015-9317-z

Kim, J. W., \& Lim, J. H. (2011). IT investments disclosure, information quality, and factors influencing managers' choices. Information and Management, 48(2-3), 114-123. https://doi.org/10.1016/j.im.2011.03.001

Kim, O., \& Verrecchia, R. E. (1994). Market liquidity and volume around earnings announcements. Journal of Accounting and Economics, 17(1-2), 41-67. https://doi.org/10.1016/01654101(94)90004-3

Kimball, M. S., \& Shumway, T. (2010). Investor sophistication and the home bias, diversification, and employer stock puzzles [Working Paper]. SSRN. https://doi.org/10.2139/ssrn.1572866

Koehler, C. (2014). Investor sophistication as a systematical criterion in the securities act of 1933. Spring. Retrieved from http://dx.doi.org/10.2139/ssrn.2511542
Law n. 6,404, of December $15^{\text {th }}$ of 1976 . (1976, December $\left.17^{\text {th }}\right)$. Discusses joint-stock companies. Retrieved from http://www. planalto.gov.br/ccivil_03/leis/16404consol.htm

Mao, J. C. T., \& Helliwel, J. F. (1968). Investment decision under uncertainty: Theory and practice. The Journal of Finance, 24(2), 28-30.

Moshirian, F., Ng, D., Wu, E. (2009). The value of stock analysts' recommendations: Evidence from emerging markets. International Review of Financial Analysis, 18(1), 74-83.

Sias, R. W., \& Starks, L. T. (1997). Return autocorrelation and institutional investors. Journal of Financial Economics, 46(1), 103-131. https://doi.org/10.1016/S0304-405X(97)00026-3

Sidhu, B., \& Tan, H. C. (2011). The performance of equity analysts during the global financial crisis. Australian Accounting Review, 21(1), 32-43.

Snow, C. C., \& Hambrick, D. C. (1980). Measuring organizational strategies: Some theoretical and methodological problems. Academy of Management Review, 5(4), 527-538.

Verrecchia, R. E. (2001). Essays on disclosure. Journal of Accounting and Economics, 32(2001), 97-180.

Zaini, S. M. D., Samkin, G., Sharma, U., \& Davey, H. (2018). Voluntary disclosure in emerging countries: a literature review. Journal of Accounting in Emerging Economies, 8(1), 29-65. 